\title{
PETRUS VAN MUSSCHENBROEK (1692-1761) ON THE SCOPE OF PHYSICA AND ITS PLACE WITHIN PHILOSOPHIA
}

\author{
Steffen Ducheyne \\ Vrije Universiteit Brussel \\ steffen.ducheyne@vub.ac.be
}

Received: December 2, 2014; Accepted: February 5, 2016.

Cómo citar este artículo/Citation: Ducheyne, Steffen (2016), "Petrus Van Musschenbroek (1692-1761) on the scope of physica and its place within philosophia", Asclepio 68 (1): p123. doi: http://dx.doi.org/10.3989/asclepio.2016.02

\begin{abstract}
As a supplement to John L. Heilbron's account, I will argue that, although the label 'experimental physics' can be rightfully used to describe aspects of Petrus van Musschenbroek's (1692-1761) work, the latter's understanding of 'physica' is to be situated within a broader framework in which theological, philosophical and teleological considerations continued to play an important role. First, I will draw attention to Musschenbroek's views on the scope of physica and especially to his conception of a law of nature. It will be shown that by radicalizing certain aspects of Isaac Newton's methodological ideas van Musschenbroek no longer considered physics as the discipline that uncovered causes from effects, as Newton did, but as the discipline that studies the effects of unknown causes. In addition, I will show that van Musschenbroek endorsed the view that the laws of nature are contingent on God's free will and that they are knowable due to his goodness. Second, it will be argued that for van Musschenbroek physics, alongside with teleology, had clear physico-theological repercussions. Along the way, van Musschenbroek's views on the principle of sufficient reason will be discussed for the first time.
\end{abstract}

KEYWORDS: Petrus van Musschenbroek (1692-1761); Natural philosophy versus (experimental) physics; Physica; Teleology; Laws of nature; Voluntarism; Principle of sufficient reason.

\section{PETRUS VAN MUSSCHENBROEK (1692-1761) EN EL ÁMBITO DE LA PHYSICA Y SU LUGAR EN LA FILOSOFÍA}

RESUMEN: Como complemento al relato de John L. Heilbron, argumentaré que aunque la etiqueta 'física experimental' se puede usar legítimamente para describir algunos aspectos de la obra de Petrus van Musschenbroek (1692-1761), la comprensión de la 'physica' de este último se ha de entender dentro de un marco más amplio en el que las consideraciones teológicas, filosóficas, y teleológicas continuaron desempeñando una función importante. En primer lugar, me centraré en la concepción de van Musschenbroek en el ámbito de la 'physica' y en especial en su concepto de una ley de la naturaleza. Se verá que, al radicalizar algunos aspectos de las ideas metodológicas de Isaac Newton, van Musschenbroek ya no se considera la física como la disciplina que descubre las causas de efectos, como hizo Newton, sino como la disciplina que estudia los efectos de causas desconocidas. Además, se verá que van Musschenbroek pensaba que las leyes de la naturaleza están supeditadas a la libre voluntad de Dios y que son cognoscibles debido a la bondad de Dios. En segundo lugar, argumentaré que para van Musschenbroek la física, junto con la teleología, tenía claras repercusiones físico-teológicas. En el camino, por primera vez discutirá su posición en relación con el principio de razón suficiente.

PALABRAS CLAVE: Petrus van Musschenbroek (1692-1761); Filosofía natural versus física (experimental); Physica; Teleología; Leyes de la naturaleza; Voluntarismo; Principio de razón suficiente.

Copyright: (c) 2016 CSIC. This is an open-access article distributed under the terms of the Creative Commons Attribution License (CC BY) Spain 3.0. 


\section{INTRODUCTION ${ }^{1}$}

Petrus (Pieter) van Musschenbroek (1692-1761; see Fig. 1) was one of the most renowned eighteenth-century Dutch experimental philosophers. Before returning to the University of Leiden in 1740 , where he obtained his doctoral degree in medicine in 1715 with a dissertation on the presence of air in animal fluids (van Musschenbroek, 1715), van Musschenbroek, who descended from a family of instrument makers, was previously appointed at the University of Duisburg (1719-1723) and at the University of Utrecht (1723-1739). ${ }^{2}$ Like his colleague Willem Jacob 's Gravesande (1688-1742), van Musschenbroek spent some time in England: in 1717 he travelled to London to attend J. T. Desaguliers' (1683-1744) lectures on experimental philosophy - unfortunately, further details about his stay in England are lacking.

Fig. 1. Engraving by Jacob Houbraken of Petrus van Musschenbroek which is based on a painting by Jan Maurits Quinckhard (1738).

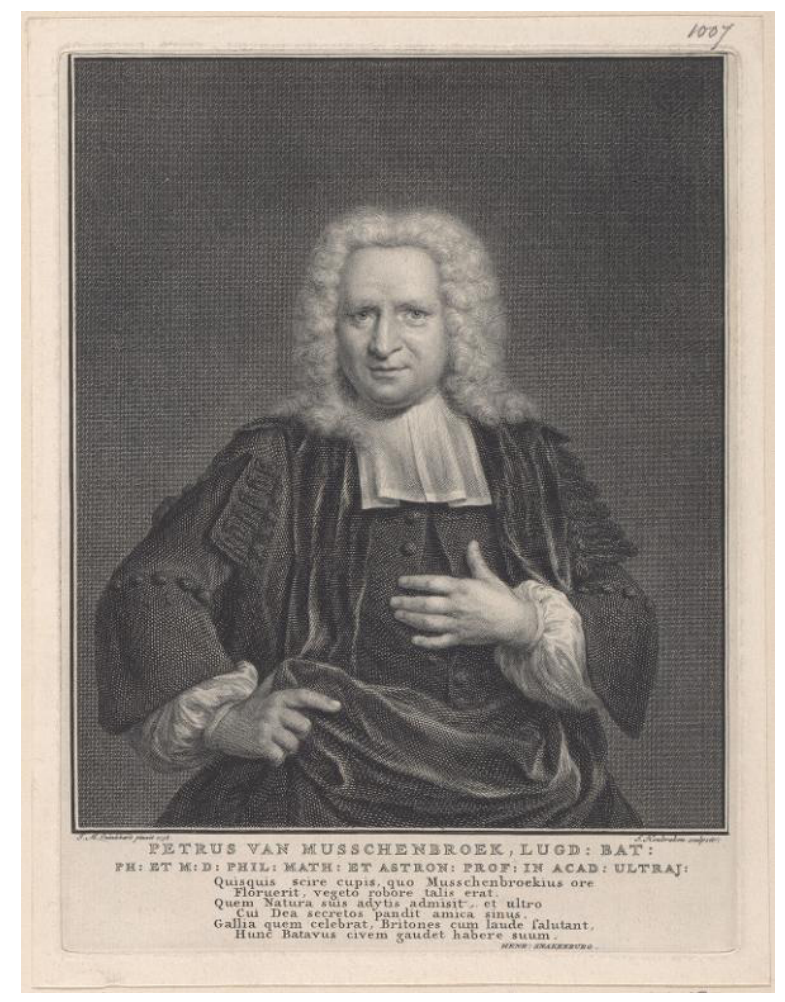

Source: Leiden University Library, Digital Special Collections, BN 1007.

The above woodcut was printed in van Musschenbroek, 1739, which is based on Beginsels der natuurkunde (1739), i.e. the second edition of Beginselen der natuurkunde (1736), which was dedicated to the Amsterdam Mennonite and owner of the Utrechtbased filature 'Zijdebalen' David van Mollem (1670-
1746) "as a sign of esteem and true friendship" (see Hamm, 2012, pp. 36-37 for further contextualization). Henrik Snakenburg's (1674-1750) verses read:

Whoever desires to know by what appearance van Musschenbroek blossomed, it was with such vivid strength. Whom Nature has admitted by her shrines and to whom she spontaneously unfolded her secret bosom like a friendly Goddess. Whom France celebrates and whom the English salute with praise. Here Holland rejoices having him as citizen.

Today, van Musschenbroek is remembered for a variety of reasons, mostly for strictly 'scientific' ones. He contributed to the study of magnetism as his Dissertatio physica experimentalis de magnete (1729) testifies (van Musschenbroek, 1729, pp. 1-270), and he developed a famous pyrometer. ${ }^{3}$ Together with his collaborators Jean-Nicolas-Sébastien Allamand (17131787) and Andreas Cunaeus (1712-1788), he also made -independently from Ewald Georg von Kleist (1700-1748) - one of the first capacitors, the famous 'Leyden jar', ${ }^{4}$ which upon its discovery produced such a shock that in a letter on 20 January 1746 van Musschenbroek wrote to René-Antoine Ferchault de Réaumur (1683-1757):

I would like to tell you about a new but terrible experiment, which I advise you never to try yourself, nor would I, who have experienced it and survived by the grace of God, do it again for all the kingdom of France (quoted from Heilbron, 1999, p. 313). ${ }^{5}$

Van Musschenbroek is also known as an enthusiastic teacher, whose textbooks were highly influential across Europe. ${ }^{6}$ After 's Gravesande's death in 1742, van Musschenbroek was in full charge of teaching experimental philosophy at his alma mater. In his eulogy, Nicolas de Condorcet (1743-1794), stated that "while his [i.e. van Musschenbroek's] books contained only cold truths, the enthusiasm which animated his lessons excited that of his listeners" (Condorcet O'Connor and Arago, 1847, vol. II, p. 127). ${ }^{7}$ Van Musschenbroek's most comprehensive textbook, the more than 1100 pages long and posthumously published Introductio ad philosophiam naturalem (van Musschenbroek, 1762), ${ }^{8}$ which according to John L. Heilbron exemplified eighteenth-century 'experimental physics' like no other textbook had before (Heilbron, 1980, pp. 363-367; see, furthermore, Guijarro Mora, 2001), was the pinnacle of his lifelong scientific activities. Heilbron considers van Musschenbroek as a prototypical example of the eighteenth-century experimental physicist. "In multiplying measurements and experiments he had no superior," Heilbron underscores, "his 
books filled with tables and drawings initiated generations into the study of experimental physics [...]" (HeiIbron, 1980, pp. 365/7, cf. p. 363).

Can we, however, simply equate what van Musschenbroek labelled 'physics' - 'physica' in Latin; 'natuurkunde' in his own vernacular - with what Heilbron calls 'experimental physics'? Although it is true that during the eighteenth century natural philosophy in general gradually lost its metaphysical, causal and theological underpinnings and became the more experimental, quantitative and instrumentalist discipline which we now call 'physics' (Heilbron, 1999, pp. 9-19, pp. 71-73; Home, 2003; Frängsmyr et al., 1990), van Musschenbroek is to be considered as a transitional figure in the shift from natural philosophy to physics for reasons that will become more clear in what follows. As a supplement to Heilbron's account, I shall argue that, although the label 'experimental physics' can be rightfully used to describe aspects of van Musschenbroek's work, the latter's understanding of 'physica' is to be situated within a broader framework in which theological, philosophical and teleological considerations continued to play an important role. I will argue for this claim in two steps. First, I will draw attention to van Musschenbroek's views on the scope of physica and especially to his conception of a law of nature in the next section. It will be shown that by radicalizing certain aspects of Newton's methodological ideas van Musschenbroek no longer considered physica as the discipline that uncovered causes from effects, as Newton did, but as the discipline that studies the effects of unknown causes. This aspect of his thinking seems to square well with Heilbron's instrumentalist characterization of experimental physics. However, it will be pointed out that van Musschenbroek thought that the laws of nature are -in a way unknown to us - contingent on God's free will and that they are knowable due to God's goodness. Second, it will be argued in the third section that for van Musschenbroek physics, alongside with teleology, had clear physico-theological repercussions. Along the way, for the first time van Musschenbroek's views on the principle of sufficient reason will be brought to the fore. Throughout this essay I will approach these issues by a close reading of the entirety of van Musschenbroek's published and unpublished work. With respect to the latter it should be kept in mind that in most cases Musschenbroek's manuscripts are undated, which makes it rather difficult for the interested scholar to set up an exact chronological account of the development of his thought.

\section{"HAEC ARCANA SUNT:" VAN MUSSCHENBROEK ON THE SCOPE OF PHYSICA}

According to van Musschenbroek, the objects of physics are body (corpus), ${ }^{9}$ i.e. everything "we can see or feel, or whatever resists pressure," space (spatium), i.e. "[t]he extension of the universe in which all bodies are placed and move every way," ${ }^{10}$ and motion (motus), i.e. "the translation of body out of one part of space into another" (van Musschenbroek, 1744, vol. I, pp. 3-4; van Musschenbroek, 1741, p. 3). Because we lack innate ideas of bodies and their qualities, everything that pertains to them is learned either by observation, i.e. the perception of the qualities that bodies spontaneously offer to us, or by "experiments or trials [Experimenta, vel Pericula]," i.e. by active manipulations of bodies for the purpose of discovering those properties of bodies that do not otherwise appear to our senses (van Musschenbroek, 1762, vol. I, pp. 4-5). If the senses stay within the limits by which they are circumscribed and if they are rightly disposed, they will never deceive us. Those who assert that the senses are deceptive oppose "the sanctity of the most perfect Entity, who is the fountain of all truths [sanctitati Entis perfectissimi, omnium veritatum fontis]" (van Musschenbroek, 1723, pp. 19-20). Experiments should be repeated, van Musschenbroek emphasized: "[i]f the repeated event should agree to the prior event, we are more certain that the test has been duly made and that no error has crept in" (van Musschenbroek, 1756, xxiv). Phenomena or appearances are defined as "[a]ll the situations, motions, mutations, and actions of bodies, which we may observe by our senses, whether by one or more of them" (van Musschenbroek, 1744, vol. I, p. 4; van Musschenbroek, 1741, p. 3). This definition clearly resembles the way in which van Musschenbroek's colleague 's Gravesande characterized phenomena, namely as:

all Situations, and Motions, of natural Bodies, not immediately depending upon the Action of an intelligent Being, and which may be observed by our Senses [omnes situs, \& omnes motus, Corporum naturalium, ab actione Entis intelligentis immediate non pendentes, \& qui à nobis sensibus observari possunt] ('s Gravesande, 1747, vol. I, p. 1; 's Gravesande, 1742, vol. I, p. 1).

Since all changes in bodies ("increase, decrease, generation, corruption, or other alteration whatever") are produced by motion, motion is, according to van Musschenbroek, "the principal object of Physicks [primarium Physicæ objectum est Motus]" (van Musschenbroek, 1744, vol. I, p. 5; van Musschenbroek, 1741, p. 4). The motions of bodies occur, "whatever may be 
the cause of their motion [quæcunque causa movens existerit]," according to certain rules or laws of nature ("leges naturæ"), i.e. "those constant appearances or effects, which always occur in the same way, whenever bodies are in similar circumstances [constantes apparitiones vel effectus, qui, quotiescunque corpora in similibus sunt occasionibus, semper eodem eveniunt modo]" - consequently, phenomena that occur contrary to the laws of nature are miraculous (van Musschenbroek, 1744, vol. I, pp. 5-6; van Musschenbroek, 1741 , p. 4-5). In other words, for van Musschenbroek the aim of physica is to establish not the efficient causes of effects, but the rules according to which those effects occur. Yet again, van Musschenbroek's words remind us of 's Gravesande's, who had written that a law of nature is "every simple Effect, which continues the same upon all Occasions, whose Cause is unknown to us, and which we find cannot flow from any Law known to us, tho' perhaps it may from a more simple Law, unknown to us [omnis effectus simplex, qui in omnibus occasionibus idem est, cujus causa nobis est ignota, \& quem videmus ex nullâ Lege, nobis notâ fluere posse, quamvis fortè ex simpliciori Lege, nobis ignotâ, fluat]" ('s Gravesande, 1747, vol. I, pp. 2-3; 's Gravesande, 1742 , vol. I, p. 2). Therefore, as van Musschenbroek continued, "by knowing and observing these laws, we can often know and foresee what will be their effects." For "if we observed yesterday, that a wedge, being impelled with a certain force, clove a piece of wood; we may certainly conclude, that a wedge being impelled to day with the same force will have the same effect" (van Musschenbroek, 1744, vol. I, p. 5; van Musschenbroek, 1741, p. 4). ${ }^{11}$ Van Musschenbroek believed that the constancy of the laws of nature is ultimately guaranteed by the constancy of God's will:

The laws are discoverable only by the use of the senses; for the wisest of mortals could not have discovered any of them by reason and meditation, nor can pretend to have any innate ideas of them in his mind. For they all result from the arbitrary appointment of the Creator [a liberrimâ Creatoris voluntate], by which he has ordered, that the same constant motion shall always obtain on the same occasions. [...] All these things might have been otherwise constituted [by God's infinite power], ${ }^{12}$ if God had so pleased [voluisset]. And why he thought fit to constitute them in this manner, we can by no means apprehend. It is sufficient for us to know, that they are thus constituted, and to adore the infinite wisdom of the Creator, in this most admirable order and constitution of the universe. Therefore the cause and reason [causa \& ratio] of these laws are entirely unknown to us, but we know they will perpetually be observed, because the divine will acts always in the most constant and uniform manner [quia voluntas divina constantissima est]. (van Musschenbroek, 1744, vol. I, pp. 5-6 [italics added]; van Musschenbroek, 1741, pp. 4-5)

"The laws [of nature] are all truly most constant," he elaborated, "because divine will and providence are most constant and perfect, since God is always the same absolutely perfect, wise and immutable being" (van Musschenbroek, 1762, vol. I, p. 8). Without the constancy of God's operations the human race would be in a miserable state for want of certain knowledge (van Musschenbroek, 1736, p. 7). The goodness of God is clear "because nothing which is created is absolutely necessary [quia nihil quod creatum est, absolute necessarium est]" and because "he conserves us and the things he created at the time according to most simple, immutable and good laws [quia nos conservat, tum \& creata, secundum leges simplicissimas, immutabiles, optimas]" (van Musschenbroek, 1762, vol. I, p. 5). Like 's Gravesande (Ducheyne, 2014a, pp. 43-44), van Musschenbroek believed that God's goodness ultimately provides the secure foundation of our knowledge of the world. According to van Musschenbroek, only God is an "absolutely necessary being [Ens absolute neccesarium]" (LUL, BPL 240.7, f. 11 $\left.11^{\mathrm{v}}\right) .^{13}$ The anti-Spinozist impact of this statement should not be underestimated. As I have documented elsewhere (Ducheyne, 2014c), since at least the mid-1720s van Musschenbroek took serious issue with Spinoza's philosophical system, in particular with his metaphysical necessitarianism according to which " $[t]$ hings could have been produced by God in no other way, and in no other order than they have been produced" (Curley, 1985, p. 436). ${ }^{14}$

Van Musschenbroek emphasized that we are ignorant as to whether the laws of nature immediately flow from God or whether they are produced by intermediate causes:

And thus from our perspective the laws [of nature] are simple effects which are the same in all similar circumstances and which we will not see to follow from any other law, the cause so to speak, even if they happened to flow from another more simple or general law. For our [law] does not proclaim whether it immediately depends on the will of God, or whether is it caused by an unknown proximate cause which mediates and antecedes or by a long series of other causes. (van Musschenbroek, 1762, vol. I, p. 7)

The word 'tanquam' ('so to speak'; 'as if') is crucial here, for is indicates that van Musschenbroek, in line with his definition of a law of nature as "every simple Effect, which continues the same upon all Oc- 
casions, whose Cause is unknown to us," did not consider laws as real efficient causes. In identical vein, 's Gravesande claimed that "it matters not, whether any thing depends immediately upon the Will of God, or is produc'd by an intermediate Cause, of which we have no Idea [non interest, utrùm quid immediatè à Dei voluntate pendeat, an verò mediante causâ, cujus nullam ideam habemus, producatur]" ('s Gravesande, 1747, vol. I, p. 2; 's Gravesande, 1742, vol. I, pp. 2-3). Van Musschenbroek urged that, since only a few laws of nature have been discovered, we ought "to search them out diligently [sollicite]" (van Musschenbroek, 1744, vol. I, p. 6; van Musschenbroek, 1741, p. 5). However, "because nature abounds with such variety," he observed, "we ought not to establish general rules from a few trials [ne extemplo ex paucorum examine generales Leges stabiliamus], which can only afford us particular conclusions;" rather, we ought to proceed slowly (van Musschenbroek, 1744, vol. I, pp. 6-7; van Musschenbroek, 1741, p. 6; cf. van Musschenbroek, 1736, p. 8). "Nature," as van Musschenbroek remarked amongst his notes in his own copy of Beginsels der natuurkunde (1739), is not "as parsimonious as some Philosophers have imagined [niet zo spaarzaam [...] als Sommige Wijsgeeren zich verbeelden]" (LUL, BPL 240.61, p. 10)..$^{15}$

Like 's Gravesande (Ducheyne, 2014a, pp. 35-36), van Musschenbroek clearly rejected the idea that we can know the essences of bodies:

Now that many of the attributes of body may be still unknown, is evident from thence, because we can observe only by the help of our senses, how it is with the superficies of bodies. We only see the surface with our eyes, touch it with our hands, taste nothing but this with our tongue, nor smell any thing else with our nostrils. But what is that which is included within [hæret] the superficies of body? Is not this the thing that properly makes the body, and is it's substance? But this we know nothing of. So that we know nothing but the shell of body [corticem corporis], and a few things that we collect besides from the phænomena, but not that which constitutes the intimate nature of the body [non autem id, quod corpus constituit, cognoscimus][.] (van Musschenbroek, 1744, vol. I, pp. 12-13, cf. p. 25; van Musschenbroek, 1741, pp. 22-23, cf. p. 36) ${ }^{16}$

According to van Musschenbroek, humans can only acquire knowledge of the essences and essential attributes of mathematical objects, but they cannot know the nature "of God, of all things created, whether spiritual or corporeal, or of space, although in all of these things there is a certain nature [nec Dei, nec ullarum rerum creatarum, sive spiritualem, sive corporearum, sive spatii naturam cognoscimus: nihilominus omnibus his rebus natura quaedam inest]" (van Musschenbroek, 1748b, p. 7). ${ }^{17}$ Correspondingly, the attributes and qualities of bodies and the laws of nature cannot be known a priori by metaphysical speculation (van Musschenbroek, 1744 , vol. I, p. 14 , p. 26, p. 35; van Musschenbroek, 1741 , p. 12 , p. 23, p. 32). We "cannot inspect into the internal substance of bodies [in Substantiam corporum internam introspicere nobis non licet]; nor do we understand how heavy bodies, that are remote from one another, can operate upon each other [in se mutuo operabuntur], when nothing intervenes between them," for "[w]e see or understand nothing, but the constant effects of this [attracting] force [nihil præter effectus quotidianos videmus, aut intelligimus]" (van Musschenbroek, 1744, vol. I, p. 200; van Musschenbroek, 1741, p. 185). In view of this, the cause of gravity is unknown and all proposals on the matter are mere hypotheses (van Musschenbroek, 1744, vol. I, p. 106, p. 199; van Musschenbroek, 1741, p. 99, p. 184). The word 'attraction' in other words does not refer to "a mode of action," but rather to the effect or the phenomenon (van Musschenbroek, 1744, vol. I, p. 197; van Musschenbroek, 1741, p. 182). Although, "it is very evident, that bodies cannot approach one another, but there must be some active principle [Principium aliquod activum], that is able to produce such a motion," we are "at a loss about those principles" (van Musschenbroek, 1744, vol. I, p. 198, p. 200; van Musschenbroek, 1741, p. 183, p. 185): ${ }^{18}$

If we consider the phenomena which the bodies themselves present us with, we shall be easily induced to admit such active principles, as are the cause of gravitation and attraction. By virtue of these principles bodies tend to one another, rush upon one another, and those that touch cohere no otherwise than as if they were pressed to one another by some external force. [...] But we cannot produce these principles to view, nor tell how many or what they are, because our senses are not acute enough to penetrate into the inward substance of bodies, but there are many things whose existence must be allowed, though we may be entirely ignorant of their nature [multa sunt, quae esse concedimus, qualia sint, ignoramus.]. (van Musschenbroek, 1744, vol. I, p. 198, pp. 199-200; van Musschenbroek, 1741, pp. 184-185)

Van Musschenbroek seized Newton's admission that the cause of gravity is unknown as an opportunity to point, more generally, to our ignorance of the operations of nature in general: ${ }^{19}$

Perhaps the manner, in which the attractive force operates, will never be known; and such a degree of 
knowledge is never to be attained by the ablest Philosophers; for indeed we do not understand the manner of operating of any one thing; and all we can do is to observe effects that constantly flow from thence. [...] All these mysteries are concealed from us mortals [Omnia hæc mortales latent]. Those that think they very well understand the impulse of bodies, because manifest effects of it continually present themselves before their eyes, seem not at all to consider what produces those effects, nor to distinguish between cause and effect. Nor is it better understood, how the human body acts upon an incorporeal mind, or how the mind acts upon the body; or how a spirit can act upon a spirit. These things will always be secrets to us, into which we are not permitted to penetrate [hæc arcana sunt, in quæ penetrare nobis concessum non est]. Let us therefore leave these fruitless enquiries, and apply ourselves carefully to observe effects, and to make proper experiments, that we may have sure and firm foundations to reason upon; and that quitting all prejudice and prepossession, and avoiding party decisions, as also the itch of disputing, we may pursue truth only, promote science, and so direct our united studies and endeavours, that they may terminate in the general benefit of mankind. (van Musschenbroek, 1744, vol. I, viii-x [italics added]; van Musschenbroek, $1741, * 5 b-* 6 b)$

Together with 's Gravesande, van Musschenbroek contributed to an important transformation within eighteenth-century natural philosophy: whereas for Isaac Newton "the main Business of natural Philosophy is to argue from Phaenomena without feigning Hypotheses, and to deduce Causes from Effects" (Newton, 1952, p. 369 [italics added]), ${ }^{20}$ for van Musschenbroek (and for's Gravesande) it became the study of the effects (of unknown causes) (Ruestow, 1973, p. 127, p. 138). Moreover, whereas Newton considered the search for the cause of gravity as a worthwhile enterprise (Newton, 1952, cxxiii), van Musschenbroek (and 's Gravesande) simply rejected it outright as a futile endeavour. Van Musschenbroek also changed the goal of physics from the search for efficient causes to the search for universal regularities and in doing so he gradually turned it into physics. However, for van Musschenbroek physica was, as we will now see in the next section, still part of a broader disciplinary whole: philosophy. Furthermore, he endorsed the view that it is possible to know the final causes of things by studying the results obtained in physics.

\section{"MIRACULA DIVINA IN CLARISSIMA LUCE PONIT": PHYSICA'S PLACE WITHIN PHILOSOPHIA}

According to van Musschenbroek, 'physica' is a part of philosophy. ${ }^{21}$ Philosophy, as he explained, is "the knowledge [Scientia] of all things both divine [i.e. "God himself, and all the works he has produced out of himself, whether they are spiritual, or whether they are corporeal and extended"] and human [i.e. "all the actions of men, and all artificial things contrived by them, by disposing the things they find created to their hands, in a new manner and situation"], and of their properties, operations, causes, and effects; which may be known by the understanding, the senses, reason, or by any other way whatever [Intellectu, Sensibus, Ratione, vel aliâ quacunque viâ]" (van Musschenbroek, 1744, vol. I, p. 1 [italics added]; van Musschenbroek, 1741, p. 1). The best preparation for philosophy is "a previous acquaintance with the Liberal Arts, and especially [...] Mathematics" (van Musschenbroek, 1744, vol. I, p. 3; van Musschenbroek, 1741, p. 3). The end of philosophy is "to promote the real happiness of mankind, as far as may be attained in this life" (van Musschenbroek, 1744, vol. I, p. 1; van Musschenbroek, 1741 , p. 1). Knowledge of spiritual things, on the one hand, and knowledge of corporeal things, on the other, is acquired differently: whereas spiritual beings can only be known "by reason and the understanding [Intellectu \& Ratione]," everything which is corporeal can only be known by means of the senses [Sensuum ope] (van Musschenbroek, 1744, vol. I, p. 2; van Musschenbroek, 1741, p. 1). ${ }^{22}$ According to van Musschenbroek, philosophy consists of six "parts [partes]:" to wit, pneumatica, metaphysica, practica, logica, physica, and teleologia (van Musschenbroek, 1744, vol. I, pp. 2-3; van Musschenbroek, 1741, p. 2). ${ }^{23}$ In what follows, I will discuss each of these parts, while devoting most attention to physica and teleologia.

Pneumatica comprehends "whatever belongs to spiritual existences, their attributes and operations [Spirituum Existentia, Attributis, \& Operationibus]" (van Musschenbroek, 1744, vol. I, p. 2; van Musschenbroek, 1741, p. 2). Van Musschenbroek defined a spirit simply as an incorporeal thing ("Rem incorpoream") in the annotations of one of his copies of Institutiones physicæ (1748) (LUL, BPL 240.56, f. 14v). Correspondingly, pneumatica addresses God, who is an infinite and substantially omnipresent spirit $^{24}$ and whom van Musschenbroek called "[e]ns summum, quod totus Spiritus est" (Musschenbroek, 1729, p. 2; cf. LUL, BPL 240.7, f. $11^{\text {r) }}$, and finite spirits, namely: angels, and human and animal souls (van Musschenbroek, 1736, p. 2; van Musschenbroek, 1762, p. 1). Metaphysica "explains [exponit] such general things as are in common to all created beings," such as "being, substance, mode, relation, possible, impossible, necessary, contingent, \&c." (van Musschenbroek, 1744, vol. I, 
pp. 2-3; van Musschenbroek, 1741, p. 2). Metaphysics contains both ontology, the study of the general characteristics of being, and cosmology, which treats of "the general characteristics of the universe" (van Musschenbroek, 1748a, p. 2; van Musschenbroek, 1762, vol. I, p. 3). In Beginselen der natuurkunde van Musschenbroek stated that, although metaphysics is useful, its usefulness is "less than is usually suggested [minder, als men plagt op te geeven]" (van Musschenbroek, 1736, p. 4). He also emphasized that those, "who attempt to explain natural Philosophy from Metaphysicks [qui ex Metaphysica Physicam explicare aggrediuntur]," always run into error (van Musschenbroek, 1744, vol. I, p. 35; van Musschenbroek, 1741, p. 32). ${ }^{25}$ Practica gives us "the rules, by which we should direct all our actions, in order to discharge those duties [officia] we owe to God, to ourselves, and to other men" (van Musschenbroek, 1744, vol. I, p. 3; van Musschenbroek, 1741, p. 2). Logica "considers [explicat] the intelligent and reasoning faculty of the human mind, and instructs us in the methods of reasoning justly [methodum dirigendi ingenii], and of avoiding error, and directs the understanding in it's search after hidden truths, and teaches to demonstrate them when found" (van Musschenbroek, 1744, vol. I, p. 3; van Musschenbroek, 1741, p. 2$){ }^{26}$

Physica examines "the space of the whole universe [Spatium totius Universi], and all bodies contained in it" and "enquires [indagans] into their nature, attributes, properties, actions, passions, situation, order, powers, causes, effects, modes, magnitudes, origins; proving these mathematically as far as may be done [ea Mathematice, quantum fieri potest, probans]" (van Musschenbroek, 1744, vol. I, p. 2; van Musschenbroek, 1741, p. 1). Beginselen der natuurkunde contained the following variant:

The second [i.e. the second part of philosophy] is physics, in which all created bodies, heavenly and earthly, are examined. This part deals with the properties that are common to all bodies, with their forces when they are moved, with their effects on other bodies, with all causes, which generate forces in them, and with the order according to which the major bodies are placed in the universe. This part, furthermore, deals with all bodies in particular, as it describes their figure, magnitude, gravity, and the other properties, which particular bodies possess. (van Musschenbroek, 1736, pp. 2-3)

In his annotations of his own copy of Beginsels der natuurkunde, van Musschenbroek stated that his desire to search for the causes of phenomena was "the only old yeast of the Cartesian philosophy [eenige oude zuurdeessem van de Cartesiaansche Philosophie]" still remaining in him" (LUL, BPL 240.61, interleaved folio between $* * * 2-* * * 3)$. However, as we have seen, whenever van Musschenbroek dealt with 'causes' within the domain of physica, he systematically referred to the regularities or laws of nature according to which effects always occur in the same way in similar circumstances and not to their efficient causes. ${ }^{27} \mathrm{Ac}-$ cording to van Musschenbroek, the usefulness of physics ("Utilitas Physicæ") is of no small importance:

As first for the understanding, explaining, and promoting all human arts and sciences, and chiefly the art of medicine. Secondly, it purges our minds from a vain and useless admiration of appearances, it removes the terror of death, we shall not be disturbed with those dreadful fears which commonly attend the ignorance of the nature of things, and we shall be relieved from superstition. Also this science places the divine wonders in the clearest light [hæc scientia, miracula Divina in clarissima luce ponit]. And thirdly it leads us directly to know and prove the existence of God and his providence, and to a right understanding of many of his attributes as his power wisdom, goodness, \&c. [nos ducit ad existentiam Dei, ejusque providentiam cognoscendam, probandam; tum ad ejus attributa plurima, præcipue potentiam, sapientiam, bonitatem \&c. optime intelligenda]. (van Musschenbroek, 1744, vol. I, p. 9; van Musschenbroek, 1741, p. 8)

In relation to physics, knowledge ("cognitio") is threefold: historical knowledge refers to the knowledge which we acquire by observing bodies and appearances - such knowledge is, as van Musschenbroek observed, "primary, simple, certain and the basis of physics [basis Physicæ]," philosophical knowledge refers to the knowledge we establish by discovering and demonstrating the causes of appearances, and, mathematical knowledge refers to the knowledge we obtain when "the magnitudes of the appearances and their causes are considered geometrically and what follows from them is deduced [apparitionum, \& causarum magnitudines Geometrice considerantur, \& quæ ex iis fluunt, colliguntur]" (van Musschenbroek, $1762, \mathrm{I}, \mathrm{p} .11)$. This threefold distinction is inspired by the first chapter of Christian Wolff's (1679-1754) Philosophia rationalis, i.e. De triplici cognitione humana, historica, philosophica \& mathematica (Wolff, 1736, pp. 1-13, esp. p. 3, p. 4 , p. 7). ${ }^{28}$

Teleologia, which was banish from philosophy by "Descartes and his disciples [Cartesius cum suis Sectatoribus]" (LUL, BPL 240.56, f. 18v" cf. ibid., BPL 240.54, interleaved folio facing p. 2), ${ }^{29}$ investigates "the ends [fines], for the sake of which all things in the universe 
have their existence, and all their actions, changes, and motions are performed; at least as far as human sagacity can penetrate [quantum humana sagacitate indagari possint]" (van Musschenbroek, 1744, vol. I, p. 2; van Musschenbroek, 1741, p. 2). Teleology has been mistakenly banned from the sciences. The illustrious men Gottfried Wilhelm Leibniz and especially Wolff, whose view that metaphysics is to precede physics and to provide it with appropriate principles he forcefully rejected (Wolff, 1736, p. 43), ${ }^{30}$ have rightly reintroduced it (van Musschenbroek, 1736, p. 3). Wolff actually coined the term 'teleologia' in 1728 (Wolff, 1728, p. 38). Like Newton, who in the General Scholium (1713) declared that "[w]e know him [i.e. God] only by his properties and attributes and by the wisest and best construction of things and their final causes" (Newton, 1999, p. 942 [italics added]) ${ }^{31}$ -but unlike 's Gravesande (Ducheyne, 2014a, pp. 40-41), van Musschenbroek was convinced that the final causes of things are humanly knowable to some extent. However, teleology "can never be carried to perfection [nunquam perfici poterit], because it is out of reach of men to find out all the ends which the Creator has proposed to himself [quia fines, quos sibi Deus $^{32}$ proposuit, cunctos eruere hominibus concessum non est]. And when we think we have found any of them, it can hardly be demonstrated in mathematical rigour" (van Musschenbroek, 1744, vol. I, p. 2 [italics added]; van Musschenbroek, 1741, p. 2). Although van Musschenbroek differentiated teleology from physics from a disciplinary perspective, both contribute closely to the same goal: to wit, to set forth "the infinite wisdom, power, and goodness of the omnipotent Creator [...] in all his works" (van Musschenbroek, 1744, vol. I, x). Van Musschenbroek characterized teleology's utility, as follows:

This part [of philosophy] is not without utility, for it augments our knowledge and shows the wisdom and goodness of God in the clearest light. The ends [of things] can be demonstrated more clearly at any time than the causes of many effects. It is most certain that nothing is done by God or made by human beings unless because of certain ends [...]. Teleology, as far as it is useful and cultivated by the celebrated [Christian] Wolff, ${ }^{33}$ who has in this [part of philosophy] surpassed all those who were previously born, can, however, never be perfected. (van Musschenbroek, 1762, vol. I, p. 2) $)^{34}$

In Institutiones physicæ and Introductio ad philosophiam naturalem, he introduced some additional arguments in support of the claim that teleology can never be perfected. ${ }^{35}$ Why God has created the animal and plant kingdom and the solar system in the way that he did depends “on God's good pleasure and perfect wisdom, by which he understands all things and their connections, since he is the creator and ruler of all things, but mortal beings will always be ignorant of them," he explained (van Musschenbroek, 1762, vol. I, p. 3). He also warned that it is not allowed "to extend demonstrations [concerning final causes] to similar things - except insofar as they are confirmed by new observations, because we see the manifest ends of some things, which do not have a place in similar things" (van Musschenbroek, 1762, vol. I, p. 3). Despite these critical observations, van Musschenbroek maintained that we are not entirely ignorant of teleology. Near the end of Elementa physicæ he would claim, for instance, that God created winds so that we may profit from sailing to distant parts of the world:

God has given us winds, that we may know things that are at a distance from us. For man would be an ignorant animal [inperitum Animal], and without much experience, if he were to be circumscribed by the limits of his native soil. Therefore God gave us winds, that by the navigation of ships we might be supplied with all the conveniences of life, and that we might enjoy many transmarine things we should stand in need of. That all mankind might have the benefit of such things as are produced in distant regions, that there might be intercourse among remote nations, and that thus the power, wisdom, and munificence of our liberal Creator might be more generally known and acknowledged [ita liberalissimi Conditoris potentia, sapientia, \& munificentia innotesceret]. (van Musschenbroek, 1744, vol. II, pp. 327-328 [italics added]; van Musschenbroek, 1741, p. 599)

In Beginselen der natuurkunde he asserted, moreover, that rain occurs so that the air may be cleansed from its impurities, so that plants may grow and so that there may be wells and rivers on earth (van Musschenbroek, 1736, p. 2). ${ }^{36}$

When discussing teleology in his unpublished work, van Musschenbroek paid attention to the principle of sufficient reason, ${ }^{37}$ which he ultimately rejected. In his annotated copy of Institutiones physicae (1748) he formulated the principle of sufficient reason as follows: "It is certain that nothing can be done by an intelligent Being except for certain ends. This is the principle of sufficient reason introduced by Leibniz [Certum est nihil fieri ab Ente rationali nisi propter certos fines: Est hoc principium rationis sufficientis â Leibnitsio introductum]" (LUL, BPL 240.55, verso side of the second interleaved folio between pp. 16-17, cf. LUL, BPL 240.25, f. 92') (see Fig. 2). There van Musschenbroek pointed out that the principle assumes 
that humans are able to fathom all of God's intentions. According to Gottfried W. Leibniz (1646-1716), whom van Musschenbroek characterized as someone who "cultivated metaphysics [metaphysicam ... excoluit]," but "by indulging excessively in hypotheses and insufficiently cultivating experimental philosophy, stood out insufficiently in physics" (LUL, BPL 240.9, $\left.104^{r-v}\right)$, the principle of sufficient reason states that "nothing happens without a Reason why it should be so, rather than otherwise" (Clarke, 1717, p. 21). ${ }^{38}$ Van Musschenbroek labelled Leibniz's Essais de Théodicée (1710) "a romantic fable [fabulam Romanensem]" (LUL, BPL 240.24, f. $5^{r}$ ) and he forcefully rejected his idea of harmonia praestabilitas (LUL, BPL 240.24, ff. $349^{r}-366^{v}$, ff. 394r-404v). He also rejected the necessitarianism implied in Leibniz' (and Wolff's) ${ }^{39}$ version of the principle of sufficient reason - and especially its corollary that God could not have created the world differently from how it is (LUL, BPL 240.24, ff. 65'-75v, esp. f. $65^{\vee}$ and f. $\left.71^{r}\right) .{ }^{40}$ Rational beings, such as God, are not determined by absolute necessity, but only by moral necessity (LUL, BPL 240.12, f. 51').

Fig. 2. Van Musschenbroek's version of the principle of sufficient reason (BPL 240.55, verso side of the second interleaved folio between pp. 16-17).

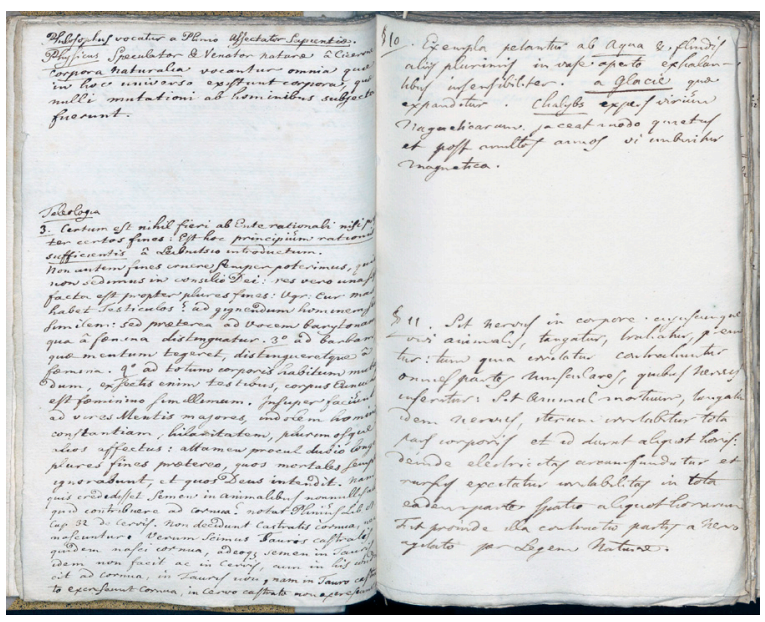

Van Musschenbroek's manuscripts contain a second locus in which he addressed the principle of sufficient reason, namely in a neatly written philosophical dictionary in which he defined key-terms in physics, medicine, chemistry, and philosophy. Although it is undated, this dictionary contains dated references - the latest one of which was published in 1756 . This suggests, considering the fact that the dictionary contains virtually no deletions or additions, that the version as we have it might have been composed thereabouts. In the lemma on the principle of sufficient reason, van
Musschenbroek states that it "was refuted by Boscovich in this treatise on the law of contiguity, p. $56, \S$ 126 [[r]efutatur a Boscovich in Tractate de Lege continuitatis pag 56. §126.]" (LUL, BPL 240.47, f. 75) (see Fig. 3). ${ }^{41}$ The most significant objection against the principle of sufficient reason that the lemma contains goes as follows: "Because liberty is taken away from God and the absolute necessity of all things that exist and the (absolute) impossibility of those things that do not exist is introduced [Quia in Deo adimitur libertas, et introducitur absoluta necessitas singularum rerum, quæ existunt, et impossibilitas earum, quæ non existunt]." Van Musschenbroek concluded the lemma with the following words: "God is such a being for which (his) will stands before reason [Deus est tale Ens, cui stat pro ratione voluntas.]" (LUL, BPL 240.47, f. 75).

Fig. 3. The lemma on the principle of sufficient reason in van Musschenbroek's philosophical dictionary (source: LUL, BPL 240.47, f. 75v).

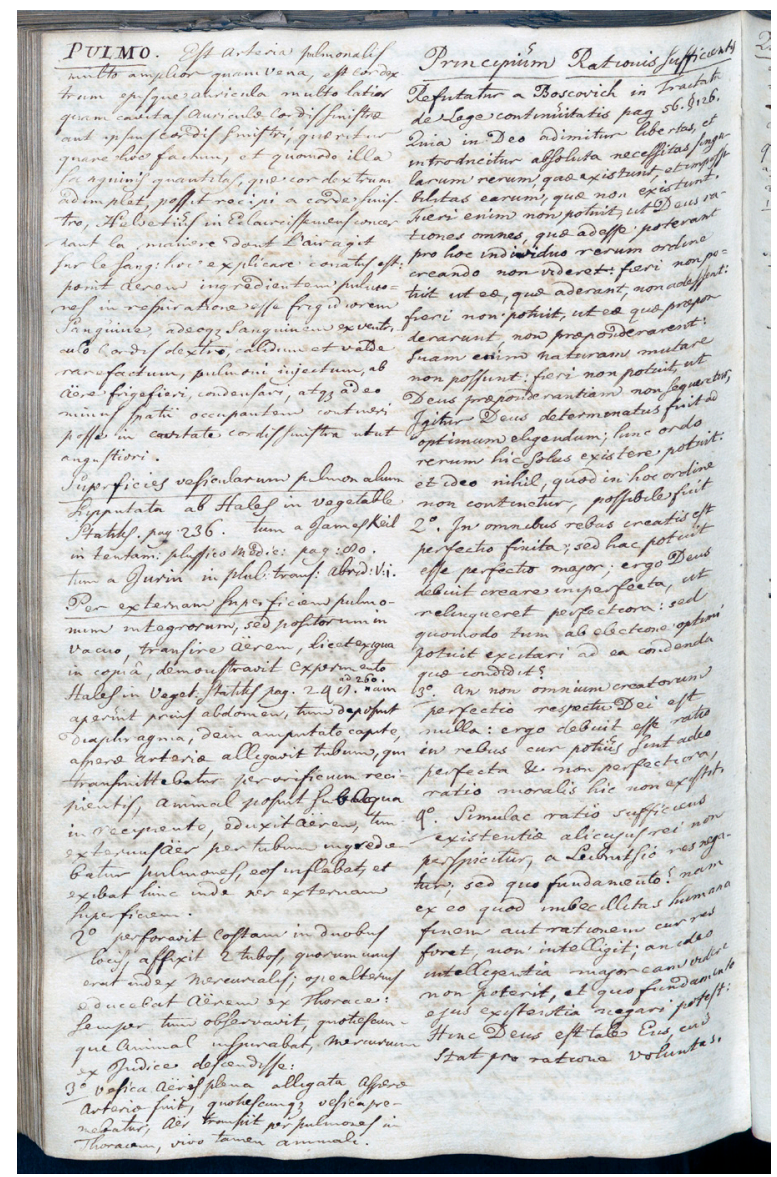

Although, because of man's limited knowledge of God's providential plan, teleology can never be brought to perfection, it is a useful branch of philosophy: it augments our knowledge, as van Musschen- 
broek argued. However, at the same time he emphasized that the utility of teleology is not restricted to a mere accumulation of knowledge: by unravelling small portions of God's teleological plan, man accomplishes his religious duty to explore to what ends God has created the universe. From the consecutive changes and additions which he introduced in his textbooks, it is clear that van Musschenbroek became more and more concerned over time with conveying this message more clearly. ${ }^{42}$

\section{CONCLUSION}

Van Musschenbroek was a key figure in an important scientific transformation, namely the transition from natural philosophy to physics. This transition did obviously not occur overnight. Instead, it was a complex and gradual process that continued throughout the nineteenth century. If we look at the state of physica in the mid-eighteenth century, Jed Z. Buchwald and Sungook Hong observe, "only a small portion of natural philosophy was quantitative or tied to exacting experiment." During the nineteenth century, physics was "transformed into a professional, unified, quantitative, and exact discipline with methods that markedly distinguished it from astronomy, chemistry, and mathematics" (Buchwald and Hong, 2003, pp. 164-165; also see pp. 166-169 for further discussion). Correspondingly, there were generations of scholars who worked in a hybrid field which was no longer strictly identifiable as philosophia naturalis as it was practiced during the seventeenth century but not quite recognizable as physics as we know it today.

As has been shown elsewhere (de Pater, 2012 and Ducheyne, 2015), van Musschenbroek's quantitative and experimental programme consisted in the collecting of large quantified sets of experimental or observational data and in the establishment of basic mathematical proportions between two or more units of measurement. Here I have shown that notwithstanding these modern features in his work theological, philosophical and teleological considerations continued to play an important role. Although van Musschenbroek contributed to the transformation of natural philosophy to physics by restricting the scope of physics to the study of universal regularities by a quantified and experimental approach, theological, philosophical and teleological issues were still deemed important and closely connected to physica. More precisely, we have seen that for him the laws of motion are contingent on the arbitrary will of God whose goodness ultimately provides the foundation of the reliability of our scientific knowledge and that in his view physica (and teleology) could contribute significantly to the worship of a divine being. Furthermore, I have brought to the fore van Musschenbroek's anti-necessitarian and voluntarist criticism of the principle of sufficient reason.

Van Musschenbroek made contributions to science which should be (and have been) studied in their own right. However, it should be kept in mind that his contributions in these areas are only one aspect of his intellectual legacy. In this essay, I have tried to show that studying the theological, philosophical and teleological underpinnings of his work provide interesting results that contribute to a better understanding of what physica meant to a key eighteenth-century researcher.

\section{ACKNOWLEDGEMENTS}

Research for this research paper is funded by the Vrije Universiteit Brussel under the form of a Research Professorship. I am thankful to the Special Collections Department at Leiden University Library and the Boerhaave Museum, Leiden, for permission to quote from or reproduce the material in their care. Parts of this essay were presented at the biennial meeting of The International Society for the History of Philosophy of Science (Ghent, 3-5 July 2014) and at the international workshops 'Early Eighteenth-century Experimental Philosophy in the Dutch Republic' (Brussels, 7 July 2014) and 'The Uses and Abuses of Mathematics in Early Modern Philosophy' (Budapest, 10 March 2015). I am indebted to the audiences of these events for their valuable comments. I am also indebted to Jip van Besouw and Pieter Present for comments on earlier versions of this essay and to the referees for this journal for their valuable feedback. I alone am responsible for any remaining mistakes. 


\section{NOTES}

1. In the absence of standard translations of van Musschenbroek's work in Latin, I will rely on eighteenth-century English translations whenever available. For important passages, I will however provide the original Latin text between square brackets. If no translation is available, I will provide my own translations.

2. On the van Musschenbroek family and Petrus van Musschenbroek's older brother Jan, the instrument maker, see de Clercq, 1997a, chapters 2 and 3. For van Musschenbroek's biographical details I have relied on Struik, 1974, de Pater (1979), pp. 24-28, Molhuysen, 1910-1924, and BML, a 251.

3. On van Musschenbroek's pyrometer, see de Pater, 1979, pp. 33-40 and de Clercq, 1997b, p. 135 [item n ${ }^{\circ} 213$ ].

4. On the Leyden jar, see de Clercq, 1997a, pp. 41-44, Heilbron, 1999, pp. 312-323, Heilbron, 1966, and, for an illustration, de Clercq, 1997b, p. 149 [item n 240].

5. The original is to be found in Nollet, 1746, p. 2078.

6. There were translations of van Musschenbroek's work in different languages (including French, English, German, Italian and Swedish) (de Pater, 1979, p. 30).

7. It is relevant here to point out that van Musschenbroek's manuscripts (ca. 12,000 folios), which are preserved at the Special Collections Department of the Leiden University Library, contain a significant amount of course texts.

8. In 1726 van Musschenbroek composed his first textbook entitled Epitome elementorum physico-mathematicorum which is to be considered as the precursor of Elementa physicæ $\left(1734^{1} ; 1741^{2}\right)$. In 1736 he published a rendition of the first edition of Elementa physicæ in his own vernacular: Beginselen der natuurkunde - its second edition appeared three years later under the title Beginsels der natuurkunde. In 1748 another update of van Musschenbroek's work appeared under the title Institutiones physicæ.

9. Van Musschenbroek endorsed "the doctrine of atoms" ("Atomorum doctrina") according to which atoms are "as it were the original particles, which God created at the beginning, and from whence all other bodies are derived [profluxerunt]" (van Musschenbroek, 1744, vol. I, p. 21; van Musschenbroek, 1741, p. 19). This doctrine, van Musschenbroek recorded, is "very ancient, and has been cultivated by Moschus, Leucippus, Democritus, Epicurus, Lucretius, Gassendus, Newton, Boerhaave, Desaguliers and others" (van Musschenbroek, 1744, vol. I, p. 21; van Musschenbroek, 1741, p. 19). Atoms are "without pores, perfectly solid, hard, firm, impenetrable, passive, moveable" (van Musschenbroek, 1744, vol. I, pp. 21-22; van Musschenbroek, 1741, p. 19). Van Musschenbroek however pleaded ignorance on the ultimate reason for the composition of matter: "For the magnitude and figure of the last and least particles depends only on the will of God [a sola voluntate Dei], who has thought fit to create them thus and not otherwise. Therefore no further reason is to be inquired after [adeoque ulterius hic inquirenda non est ratio], why these things are so. The last particles must have some magnitude and figure, and God gave them such as seemed best to his wisdom." (van Musschenbroek, 1744, vol. I, p. 26; van Musschenbroek, 1741, p. 23). God has not revealed the reasons why things are the way they are (van Musschenbroek, 1748a, p. 18; cf. van Musschenbroek, 1762, vol. I, p. 29).

10. Van Musschenbroek endorsed Newton's distinction between absolute and relative space and time (van Musschenbroek, 1744, vol. I, pp. 57-58; van Musschenbroek, 1741, pp. 52-53).

11. Note that van Musschenbroek's notion of cause is abstract in the sense that it does not stipulate a modus operandi of the forces involved. Correspondingly, annotations in one of his copies of Institutiones physicæ he defined a cause as "whatever produces an effect [quicquid producit effectum]" (LUL, BPL 240.56, f. 212').

12. The words "per Infinitam potentiam" occur in the original text, but for some reason they were left out of the translation (van Musschenbroek, 1741, p. 5).

13. This manuscript contains van Musschenbroek's Oratio de astronomia (1732).

14. For further background on Spinoza's impact in the Dutch Republic, see Israel, 1995 and 2001 and van Bunge, 2001, chapter 5.

15. For a variety of reasons, van Musschenbroek had become sceptical of analogia, i.e. inductive generalization, at the latest by the early 1740s (Ducheyne, 2015).

16. The above passage was clearly inspired by the following lines of Newton's General Scholium: "We see only the shapes and colors of bodies, we hear only their sounds, we touch only their external surfaces, we smell only their odors, and we taste their flavors. But there is no direct sense and there are no indirect reflected actions by which we know innermost substances; [...]." (Newton 1999, p. 942).

17. On van Musschenbroek's treatment of (essential) attributes, which are immutable, and properties, which are accidental, see van Musschenbroek, 1748b, pp. 6-7.

18. Here van Musschenbroek, who denied that motion is essential to matter (Ducheyne, 2014c, pp. 178-179), was endorsing the "active Principles" which in Newton's opinion underlie gravitational interaction (Newton, 1952, p. 401). See Ducheyne, 2014d for additional background.

19. In the General Scholium to the second edition of the Principia (1713), Newton famously pointed out that he had "not yet assigned a cause to gravity:" "I have not as 
yet been able to deduce from phenomena the reason for these properties of gravity, and I do not feign hypotheses." (Newton, 1999, p. 943). Elsewhere I have argued that van Musschenbroek cannot be considered as a straightforward follower of Newton's doctrines and that his methodological views were different from Newton's (Ducheyne, 2015). See Ducheyne, 2014a and 2014b for a mitigation of Newton's influence on's Gravesande.

20. See, furthermore, Ducheyne, 2012, chapter 1 for additional background.

21. For van Musschenbroek's views on the origin of physics, see van Musschenbroek, 1726, pp. 5-11.

22. During his period in Duisburg, van Musschenbroek delivered an extensive lecture series on the five senses (LUL, BPL 240.28, ff. $1^{\mathrm{r}}-164^{\mathrm{v}}$ ).

23. Corresponding draft material and variants are to be found in LUL, BPL 240.9, f. $4^{r-v}$, where Wolff's "Logica" (i.e. Wolff, 1728) is mentioned explicitly (f. $4^{r}$ ), LUL, BPL 240.24, f. $1^{\text {r }}$ and LUL, BPL 240.56, ff. $1^{r}-29^{r}$. The earliest datable document in which van Musschenbroek endorsed the above division is his lecture Consilia de dirigenda studio philosophico which was read in 1730 (LUL, BPL 240.30, ff. $2^{v}-3^{r}$ ). In later work, van Musschenbroek maintained this division. In what follows, I shall document relevant additions which occur in Beginselen der natuurkunde, Institutiones physicæ, and Introductio ad philosophiam naturalem. In van Musschenbroek, 1726, p. 2, he distinguished only between physica, pneumatica, practica and logica. In any case, the influence of Wolff's division was clearly noticeable in van Musschenbroek's description of philosophy.

24. For, as van Musschenbroek argued, "power without substance cannot be conceived [potentia vero sine substantia concipi non potest]" (LUL, BPL 240.7, f. 11v).

25. In van Musschenbroek, 1756, xliii, van Musschenbroek warned against introducing metaphysics in physics.

26. On van Musschenbroek's Institutiones logicæ, see Schuurman, 2004, pp. 156-164.

27. That van Musschenbroek focused on the establishment of regularities is consistent with his experimental and observational practice (de Pater, 2012 and Ducheyne, 2015).

28. Van Musschenbroek owned several works by Wolff ([anon.], 1762, p. 82 [item $\mathrm{n}^{\circ} 458$ ]).

29. Van Musschenbroek was well versed in Descartes' metaphysics, for he composed a 259 folios long synthesis of the latter's Meditationes de prima philosophia (1641) (LUL, BPL 240.27). When criticizing Descartes' stance on final causes, he drew attention to paragraph 28 of the first part of Principia Philosophiae (1644), which was entitled "Non causas finales rerum creatarum, sed efficientes esse examinandas." (LUL, BPL 240.56, f. 19'; Adam and Tannery, 1897-1913, vol. VIII, pp. 15-16).

30. Between 1738 and 1739 Beginselen der natuurkunde (1736) met with the fierce criticism of the Dutch Wolfflian Nicolaus Engelhard (1696-1765) (de Pater, 1990 and de Clercq, 1997b, pp. 145-147. In LUL, BPL 240.56, f. $223^{r-v}$, Engelhard is presented as a dogmatic disciple of Leibniz and in van Musschenbroek's annotated copy of Elementa physicae (1734) Engelhard's metaphysical approach is contrasted with Newton's non-hypothetical method in the Opticks (LUL, BPL 240.54, interleaved folio facing p. 6). When Engelhard ordered a series of instruments from van Musschenbroek's brother, Jan, the latter quite sarcastically inquired for which purpose the former could possibly set them to use (BML, a 541 [copy of a letter of Jan van Musschenbroek to Nicolaus Engelhard on 6 October 1739]).

31. I should note that I have found no direct evidence in his manuscripts that shows that Newton was directly on van Musschenbroek's mind when discussing teleology.

32. In van Musschenbroek, 1736, vol. I, p. 3, van Musschenbroek inserted the words "in creandis \& moderandis rebus" after the word 'Deus'.

33. Cf. LUL, BPL 240.35 , f. 134 r.

34. For Wolff's views on teleology, see Wolfius, 1728, p. 38, pp. 45-46. In van Musschenbroek, 1748, p. 2, van Musschenbroek's did not make it explicit that the study of teleology is to be valued because it displays God's wisdom and goodness. There he restricted himself to the following words: "hæc pars non est expers utilitatis, cum augeat nostram cognitionem, attamen nunquam perfici poterit."

35. Since van Musschenbroek's discussion is more detailed in Introductio ad philosophiam naturalem than in Institutiones physicæ, I shall quote from the former. Corresponding manuscript material is to be found on LUL, BPL 240.56, f. 25r.

36. In the oration which he delivered on 8 February 1744 when he became rector of Leiden University, van Musschenbroek offered a cornucopia of design arguments mainly taken from the animal and plant kingdom which according to him testify of God's providential plan (van Musschenbroek, 1744). For further details, see Roosenboom, 1970 and Bots, 1972, pp. 56-57. In his oration De astronomia præstantia et et utilate quam aliis scientiis assert., which he delivered on 6 October 1732, he emphasized that astronomy provides a tool for understanding God's immensity and infinity (LUL, BPL 240.7, f. $11^{\text {r-v }}$ ).

37. On the principle of sufficient reason, see Melamed, 2010; Gurr, 1959, chapter 2, and Lovejoy, 1964, chapter 5.

38. Wolff defined a 'sufficient reason' as that "from which it is understood why something is [unde intelligitur, cur aliquid sit]" (Wolff, 1736, p. 24). 
39. Van Musschenbroek did not discuss Wolff's version of the principle of sufficient reason, but simply pointed out that Wolff followed Leibnitz on the matter (LUL, BPL 240.24, ff. 65).

40. This manuscript contains van Musschenbroek's notes to 's Gravesande's Introductio ad philosophiam (1736).

41. Van Musschenbroek was obviously referring to Boscovich, 1754, p. 56. In the lemma he is also relying heavily from material in $\S 127$, pp. 56-57.

\section{MANUSCRIPTS CONSULTED}

Boerhaave Museum Library (abbreviated as 'BML'), Leiden, a 251.

Leiden University Library, Special Collections (abbreviated as 'LUL'), BPL 240

\section{BIBLIOGRAPHY}

Adam, Charles and Paul Tannery (eds.) (1897-1913), CEuvres de Descartes (12 vols.). Paris, Léopold Cerf.

[anon.] (1762), Bibliotheca Musschenbroekiana, sive catalogus librorum. Lugduni Batavorum, S. et L. Luchtmans.

Boscovich, P. Rogerius Josephus (1754), De continuitatis lege et ejus consectariis pertinentibus ad primam materiæ elementa eorumque vires dissertatio. Romæ: Apud Venatium Monaldini Bibliopolam in via cursus.

Bots, J. (1972), Tussen Descartes en Darwin, Geloof en natuurwetenschap in de achttiende eeuw in Nederland. Assen, Van Gorcum \& Comp. N. V.

Buchwald, Jed Z. and Hong, Sungook (2003), "Physics". In: Cahan, David (ed.), From Natural Philosophy to the Sciences: Writing the History of Nineteenth-century Science. University of Chicago Press, pp. 163-195.

van Bunge, Wiep (2001), From Stevin to Spinoza, An Essay on Philosophy in the Seventeenth-century Dutch Republic. Leiden/Boston/Köln, Brill.

Clarke, Samuel (ed.) (1717), A Collection of Papers, Which passed between the late learned Mr. Leibnitz, and Dr. Clarke, In the Years 1715 and 1716. London, James Knapton.

Condorcet O'Connor, A. and M. F. Arago (eds.) (1847), Oeuvres de Condorcet (12 vols.). Paris, Firmin Didot Frères.

Curley, E. M. (ed.) (1985), The Collected Writings of Spinoza, Volume I. Princeton University Press.

de Clercq, Pieter (1997a), At the Sign of the Orient Lamp, The Musschenbroek Workshop in Leiden, 1660-1750. Rotterdam, Erasmus Publishing.
42. When combining this observation with the attention which van Musschenbroek dedicated in his Oratio de divina sapientia (1744) to final causes mitigates Krop's claim that "Musschenbroek did not return to the theme of teleology after writing the preface to his main manual of physics [i.e. Beginselen der natuurkunde (1736)]" (Krop, 2001, p. 127).

de Clercq, Pieter (1997b), The Leiden Cabinet of Physics, A Descriptive Catalogue. Leiden, Boerhaave Museum Leiden.

de Pater, C. (1979), Petrus van Musschenbroek (1692-1761), Een newtoniaans natuuronderzoeker. Utrecht, Elinkwijk.

de Pater, C. (1990), "Nicolaus Engelhard (1696-1765) en zijn kritiek of de Beginselen der natuurkunde van Petrus van Musschenbroek (1692-1761): Wolffianisme versus Newtonianisme", Tijdschrift voor de geschiedenis der geneeskunde, natuurwetenschappen, wiskunde en techniek, 13 (2), pp. 141-161

de Pater, Kees (2012), "'The Wisest Man to whom this Earth Has as Yet given Birth,' Petrus van Musschenbroek and the Limits of Newtonian Philosophy". In: Jorink, Eric and Ad Maas (eds.), Newton and the Netherlands, How Newton was fashioned in the Dutch Republic. Amsterdam: Leiden University Press, pp. 139-157.

Ducheyne, Steffen (2012), 'The main Business of Natural Philosophy:' Isaac Newton's Natural-philosophical Methodology. Dordrecht, Springer.

Ducheyne, Steffen (2014a), “W. J. 's Gravesande's Appropriation of Newton's Natural Philosophy, Part I: Epistemological and Theological issues", Centaurus, 56 (1), pp. 31-55.

Ducheyne, Steffen (2014b), “W. J. 's Gravesande's Appropriation of Newton's Natural Philosophy, Part II: Methodological Issues", Centaurus, 56 (2), pp. 97-120.

Ducheyne, Steffen (2014c), "'Celeberrimus Atheismi patronus præcedentis sæculi': Petrus van Musschenbroek's Anti-Spinozism unveiled", Lias, Journal of Early Modern Intellectual Culture and its Sources, 41 (2), pp. 173-197. 
Ducheyne, Steffen (2014d), "Newton on Action at a Distance", Journal of the History of Philosophy, 52 (4), pp. 675-702.

Ducheyne, Steffen (2015), "Petrus van Musschenbroek and Newton's 'vera stabilisque Philosophandi methodus'”, Berichte zur Wissenschaftsgeschichte, 38 (4), pp. 279-304.

Frängsmyr, Tore; John L. Heilbron and Robin E. Rider, (eds.) (1990), The Quantifying Spirit in the 18th Century. Berkeley, University of California Press.

's Gravesande, Willem Jacob (1742 ${ }^{3}$ [1720-1]), Physices elementa mathematica experimentis confirmata, sive introductio ad philosophiam Newtoniam (2 vols.). Leidae, Johannes Arnoldus Langerak, Johannes et Hermannus Verbeek.

's Gravesande, Willem Jacob (17476 [1720-1721]), Mathematical Elements of Natural Philosophy, Confirm'd by Experiments: Or, an Introduction to Sir Isaac Newton's Philosophy, trans. by J. T. Desaguliers (2 vol.). London, T. Longman e.a.

Guijarro Mora, Víctor (2001), "Petrus van Musschenbroek y la física experimental del siglo XVIII", Asclepio, 53 (2), pp. 191212.

Gurr, John Edwin (1959), The Principle of Sufficient Reason in Some Scholastic Systems 1750-1900. Milwaukee, The Marquette University Press.

Hamm, E. (2012), "Improving Mennonites in an Age of Revolution", The Conrad Grebel Review, 30 (1), pp. 24-51.

Heilbron John L. (1980), "Experimental Natural Philosophy". In: Rousseau, G. S. and Roy Porter (eds.), The Ferment of Knowledge: Studies in the Historiography of Eighteenth-century Science. Cambridge University Press, pp. 357-387.

Heilbron, John L. (1966), “A propos de l'invention de la bouteille de Leyde", Revue d'histoire des sciences et de leurs applications, 19 (2), pp. 133-142.

Heilbron, John L. (1999 [1979]), Electricity in the 17th and 18th Centuries, A Study in Early Modern Physics. Dover, New York.

Home, R. W. (2003), "Mechanics and Experimental Physics". In: Porter, Roy (ed.), The Cambridge History of Science, Volume 4: Eighteenth-century science. Cambridge University Press, pp. 354-374.

Israel, Jonathan I. (1995), The Dutch Republic, Its Rise, Greatness, and Fall 1477-1806. Oxford, Clarendon Press.

Israel, Jonathan I. (2001), Radical Enlightenment, Philosophy and the Making of Modernity 1650-1750. Oxford University Press.

Krop, Henri (2001), "Philosophia naturalis in the Dutch Republic: Physics and Philosophy during the Enlightenment", $\mathrm{Ge}$ schiedenis van de wijsbegeerte in Nederland, 12, pp. 121132.
Lovejoy, Arthur O. (1964 [1936]), The Great Chain of Being, A Study of the History of an Idea. Cambridge (Mass.), Harvard University Press.

Molhuysen, P. C. (1910-1924), Bronnen tot de geschiedenis der Leidsche Universiteit, 1574-1811 (7 vols.). 's-Gravenhage, Martinus Nijhoff.

van Musschenbroek Petrus (1723), Oratio de certa methodo philosophiæ experimentalis, Dicta publice A. D. xiii. Septemb. 1723. Trajecti ad Rhenum, Guilielmus Vande Water.

van Musschenbroek, Peter (1744), The Elements of Natural Philosophy, Chiefly intended for the Use of Students in Universities, trans. by John Colson (2 vols.). London, J. Nourse.

van Musschenbroek, Petrus (1715), Disputatio medica inauguralis de aëris praesentia in humoribus animalibus. Lugduni Batavorum, S. Luchtmans.

van Musschenbroek, Petrus (1726), Epitome elementorum physico-mathematicorum, conscripta in usus academicos. Lugduni Batavorum, Samuel Lugtmans.

van Musschenbroek, Petrus (1729), Physicæ experimentales, et geometricæ, de magnete, tuborum capillarium vitreorumque speculorum attractione, magitudine terræ, cohærentia corporum firmorum dissertationes: Ut et ephemerides meterologicæ ultrajectinæ. Lugduni Batavorum, Samuel Luchtmans.

van Musschenbroek, Petrus (1736), Beginselen der natuurkunde. Leiden, Samuel Luchtmans.

van Musschenbroek, Petrus (1739), Traité de physique, transl. by Pierre Massuet (2 vols.). Leyden, Samuel Luchtmans.

van Musschenbroek, Petrus $\left(1741^{2}\right)$, Elementa physicæ conscripta in usus academicos. Lugduni Batavorum, Samuel Luchtmans.

van Musschenbroek, Petrus (1744), Oratio de sapientia divina. Lugduni Batavorum, Samuel Luchtmans \& Filius.

van Musschenbroek, Petrus (1748a), Institutiones physicæ conscriptæ in usus academicos. Lugduni Batavorum, Samuel Luchtmans et filius.

van Musschenbroek, Petrus (1748b), Institutiones logicæ, Præcipue comprehentes artem argumentandi. Lugduni Batavorum, Samuel Luchtmans et filius.

van Musschenbroek, Petrus (1756 [1731]), Tentamina experimentorum naturalium captorum in Academia del Cimento. Viennæ, Pragæ, et Tergesti, Joannis Thomas Trattner.

van Musschenbroek, Petrus (1762), Introductio ad philosophiam naturalem, ed. by Johannes Lulofs. Lugduni Batavorum, Sam. et Joh. Luchtmans.

Newton, Isaac (1952 [1730]), Opticks, or A treatise of the reflections, refractions, Inflections \& colours of Light. Dover, New York. 
Newton, Isaac (1999), The Principia, Mathematical Principles of Natural Philosophy, A New Translation by I. Bernard Cohen and Anne Whitman, assisted by Julia Budenz. Berkeley, University of California Press.

Nollet, Jean-Antoine (1746), “Lettre de M. l'Abbé Nollet, de I'Académie des Sciences, au P. B. J. sur l'Electricité", Mémoires pour l'Histoire des Sciences et des beaux Arts, 46 (October), pp. 2074-2090.

Roosenboom, Maria (1970), “Petrus van Musschenbroek's ‘Oratio de sapientia divina'”, In: Smith, P. and R. J. Ch. V. ter Laage (eds.), Essays in Biohistory. Utrecht: International Association for Plant Taxonomy, pp. 177-194.

Ruestow, E. G. (1973), Physics at Seventeenth and Eighteenthcentury Leiden: Philosophy and the New Science in the University. Martinus Nijhoff, The Hague.

Schuurman, Paul (2004), Ideas, Mental Faculties and Method: The Logic of Ideas of Descartes and Locke and its Reception in the Dutch Republic. Leiden, Brill.
Struik, D. J. (1974), "Musschenbroek, Petrus van". In: Gillispie, Charles C. (ed.) (1970-1980), Dictionary of Scientific Biography. New York: Charles Scribner's Sons, vol. IX, pp. 594-597.

Wolff Christian (1736 3 [1728]), Philosophia rationalis, sive, Ontologia methodo scientifica pertracta. Veronæ, S. Thomas.

Wolff, Cristian (1728), Philosophia rationalis sive logica, Methodo Scientifica pertracta et ad usum scientiarum atque vitæ aptata. Francofurti \& Lipsiæ, Prostat in officina libraria Rengeriana.

Yitzhal Melamed (2010), "Principle of Sufficient Reason", The Stanford Encyclopedia of Philosophy (Winter 2012 Edition), edited by Edward N. Zalta, [online], accessible on: http:// plato.stanford.edu/entries/sufficient-reason, [accessed on 01/06/2015]. 